\title{
Reformulation of Coal-Derived Transportation Fuels: Selective Oxidation of Carbon Monoxide on Metal Foam Catalysts \\ NCSU Final Report
}

\author{
Reporting Period Start Date: $\quad$ September 25, 2001 \\ Reporting Period End Date: $\quad$ February 28, 2005 \\ Principal Authors: NC State: Mr. Paul Chin \\ Dr. Xiaolei Sun \\ Dr. George W. Roberts \\ Clemson: Dr. Amornmart Sirijarhuphan \\ Mr. Sourabh Pansare \\ Dr. James G. Goodwin, Jr. \\ Dr. Richard W. Rice \\ Louisiana State University: Dr. James J. Spivey \\ Date Report Issued: June 1, 2005 \\ DOE Award Number: $\quad$ DE-FG26-O1NT41277
}

\author{
North Carolina State University \\ Department of Chemical and Biomolecular Engineering \\ Raleigh, NC 27695-7905 \\ Clemson University \\ Department of Chemical Engineering \\ Clemson, SC 29634-0909 \\ Louisiana State University \\ Department of Chemical Engineering \\ Baton Rouge, LA 70810 \\ Porvair Advanced Materials \\ 700 Shepherd Street \\ Hendersonville, NC 28792
}




\section{Disclaimer:}

This report was prepared as an account of work sponsored by an agency of the United States Government. Neither the United States Government nor any agency thereof, nor any of their employees, makes any warranty, express or implied, or assumes any legal liability or responsibility for the accuracy, completeness, or usefulness of any information, apparatus, product, or process disclosed, or represents that its use would not infringe privately owned rights. Reference herein to any specific commercial product, process, or service by trade name, trademark, manufacturer, or otherwise does not necessarily constitute or imply its endorsement, recommendation, or favoring by the United States Government or any agency thereof. The views and opinions of authors expressed herein do not necessarily state or reflect those of the United States Government or any agency thereof. 


\section{Executive Summary}

Hydrocarbon fuels must be reformed in a series of steps to provide hydrogen for use in proton exchange membrane fuel cells (PEMFCs). Preferential oxidation (PROX) is one method to reduce the $\mathrm{CO}$ concentration to less than $10 \mathrm{ppm}$ in the presence of $\sim 40 \% \mathrm{H}_{2}$, $\mathrm{CO}_{2}$, and steam. This will prevent $\mathrm{CO}$ poisoning of the PEMFC anode. Structured supports, such as ceramic monoliths, can be used for the PROX reaction. Alternatively, metal foams offer a number of advantages over the traditional ceramic monolith.

Reaction studies were conducted on catalysed structured supports using a fixed bed adiabatic reactor with an online non-dispersive IR gas analyzer. A study on ceramic monoliths showed that higher Fe loadings in a $5 \mathrm{wt} \% \mathrm{Pt} / \mathrm{Fe} / \gamma-\mathrm{Al}_{2} \mathrm{O}_{3}$ washcoat increased $\mathrm{CO}$ and $\mathrm{O}_{2}$ conversions and decreased $\mathrm{CO}$ selectivity. A study on metal foams showed that lower cell density and higher pores per inch foams exhibited higher CO conversions and selectivity. Under most operating conditions, the $\mathrm{CO}$ conversion and selectivity of the best $5 \mathrm{wt} \% \mathrm{Pt} / 0.5 \mathrm{wt} \% \mathrm{Fe}$ metal foam catalysts were comparable to those on a ceramic monolith with the same washcoat composition. Comparison tests showed lower CO conversion and selectivity for catalysts prepared on ceramic foam and the metal monolith supports, compared to catalysts of the same composition on metal foam and ceramic monolith supports.

Two important phenomena limit the PROX reaction: the reverse water-gas-shift (r-WGS) reaction, and transport resistances. Under adiabatic conditions, the r-WGS reaction made it impossible to achieve outlet $\mathrm{CO}$ concentrations approaching $10 \mathrm{ppm}$. The metal foam catalysts showed less r-WGS activity than the ceramic monolith catalysts. The effects of space velocity and linear velocity were studied independently using various catalyst lengths and flow rates. The CO conversion increased at higher linear velocities, which suggested a significant mass transfer resistance between the bulk gas and the catalyst surface at the lowest linear velocities.

Carbon monoxide pulse chemisorption and temperature programmed desorption (TPD) were used to determine the number of active metal sites. Pulse chemisorption and TPD experiments on the blank reactor and the blank metal foam wrapped with glass wool insulation showed no $\mathrm{CO}$ adsorption. No $\mathrm{CO}$ adsorption was observed from pulse chemisorption tests on the ceramic fiber insulation. However, considerable $\mathrm{CO}$ desorption was observed from TPD tests. On catalysed supports, an elongated tail in the pulse chemisorption tests was attributed to $\mathrm{CO}$ adsorption on either the $\gamma-\mathrm{Al}_{2} \mathrm{O}_{3}$ washcoat or on surface impurities. The pulse chemisorption and TPD results did not correlate with catalyst performance. Higher $\mathrm{CO}$ adsorption on the catalyst surface did not correspond to higher $\mathrm{CO}$ conversions from the PROX reaction.

Scanning electron microscopy (SEM) and catalyst cycling experiments were conducted to characterize the washcoats. Thermal and mechanical cycling did not cause an appreciable loss of washcoat from a metal foam. The SEM images of catalysed metal foams revealed a heterogeneous washcoat thickness and an inconsistent washcoat 
deposition. Qualitatively, no distinct differences were seen between virgin and "used" metal foams or metal foams with different pores per inch and densities. The SEM images of catalysed ceramic monoliths revealed a more uniform washcoat compared to metal foams. This might be attributed to strong variations in surface tension on the metal foams. The structure of foams is more irregular than straight-channel monoliths, leading to more surface tension variation in foams. There is a need to develop a consistent and uniform washcoat procedure for metal foams. Future work should focus on electrodeposition as a washcoat deposition technique.

Selective oxidation of $\mathrm{CO}$ in hydrogen is an important reaction for producing hydrogen from hydrocarbons suitable for use in fuel cells. Pt has been shown to be very active for this reaction. The impact of $\mathrm{Fe}$ promotion on $\mathrm{Pt} / \gamma-\mathrm{Al}_{2} \mathrm{O}_{3}$ was studied using heavily isotopic transient kinetic analysis (ITKA). In this study, Fe promotion was found to have an impact on activity, selectivity and also time-on-stream behavior of surface reaction parameters. It increased activity and selectivity, as has been also noted by others. ITKA revealed that the higher activity of PtFe is mainly due to an increase in intrinsic site activity when compared to non-promoted Pt. Fe promotion did not affect significantly the total concentration of active intermediates.

The $\mathrm{Pt} / \gamma-\mathrm{Al}_{2} \mathrm{O}_{3}$ was found to exhibit steady activity for selective $\mathrm{CO}$ oxidation after an initial rapid partial deactivation. The PtFe catalyst also showed rapid initial partial deactivation similar to Pt. The activities of both catalysts decreased with time-on-stream about the same degree in reaching a pseudo-steady-state. Unlike for Pt where initial partial deactivation was due primarily to a decrease in active intermediates, the initial rapid partial deactivation for PtFe was the result of both a decrease in the concentration of surface intermediates and a decrease in the average intrinsic site activity, but mainly due to a decrease in the intrinsic site activity. The intrinsic site activity of PtFe approached that of Pt with TOS. It would appear that carbon deposition causes the initial partial deactivation on Pt and may partially do so on PtFe. However, evidence suggests that reoxidation of Fe may also be a significant cause of the loss of activity of PtFe. As partial deactivation proceeds, the effect of Fe promotion of the Pt sites decreases.

For the selective oxidation of $\mathrm{CO}$ on $\mathrm{Pt} / \gamma-\mathrm{Al}_{2} \mathrm{O}_{3}$ at relatively low temperatures, one can increase the rate of $\mathrm{CO}$ oxidation without significantly affecting selectivity by changing the operating conditions (total pressure, temperature) and thus the surface concentration of intermediates. Since the reaction appears to be limited by the amount of adsorbed oxygen, increasing oxygen adsorption by either increasing temperature or total pressure increases the overall rate of reaction. Loss of hydrogen (nonselective oxidation) and the amount of oxygen consumed can be minimized by using higher operating pressures instead of an increased $\mathrm{O}_{2} / \mathrm{CO}$ ratio to get higher $\mathrm{CO}$ conversion. The results showed that increasing reaction temperature and total pressure had similar effects on the overall activity and surface kinetic parameters of the Pt catalyst for the selective oxidation of CO. 


\section{Table of Contents}

Disclaimer

$\underline{\text { Page }}$

Executive Summary $\quad$ iii

Table of Contents $\quad$ v

List of Graphical Materials $\quad$ vi

1. Background 1

2. Scanning Electron Microscopy 1

2.1 Theory 2

2.2 Catalysed Supports: Preparation Procedure 3

2.3 "Used" 20 ppi, 12\% $\rho$ Metal Foam Images 5

2.4 "Virgin" 20 ppi, 12\% $\rho$ Metal Foam Images 7

2.5 "Used" 40 ppi, $4 \%$ p Metal Foam Images 8

2.6 "Used” 400 cpsi Ceramic Straight-Channel Monolith Images 12

3. Catalyst (Thermal and Mechanical) Cycling 15

3.1 Mechanical Cycling $\quad 15$

3.2 Thermal Cycling 16

4. Conclusions 16

$\begin{array}{ll}\text { 5. Recommendations } & 17\end{array}$

$\begin{array}{ll}\text { 6. Acknowledgements } & 17\end{array}$

$\begin{array}{ll}\text { 7. References } & 17\end{array}$

8. List of Acronyms and Abbreviations 18 


\section{List of Graphical Materials}

List of Tables:

Table 1: X-ray photon energies for relevant elements.

List of Figures:

Figure 1: Schematic of the SEM (a) machine operation and (b) the electron optics 2 [7].

Figure 2: Schematic describing the sectioning of the supports into three pieces: 24 "end" pieces and one "middle" piece.

Figure 3: SEM images of a "used" $5 \mathrm{wt} \% \mathrm{Pt}, 0.5 \mathrm{wt} \% \mathrm{Fe}, 20 \mathrm{ppi}, 12 \% \rho$ metal foam (a) strut (SE image, scale: $200 \mu \mathrm{m}$ ) and (b) the strut at 10,000x (SE image, scale: $5 \mu \mathrm{m})$

Figure 4: SEM images of a sectioned, "used" 5 wt $\%$ Pt, 0.5 wt $\%$ Fe, 20 ppi, $12 \%$ $\rho$ metal foam from the (a) front "end" piece (SE image, scale: $100 \mu \mathrm{m}$ ), (b) back "end" piece (BSE image, scale: $200 \mu \mathrm{m}$ ), and (c) "middle" piece (SE image, scale: $200 \mu \mathrm{m}$ ).

Figure 5: SEM images of a sectioned, virgin, $5 \mathrm{wt} \% \mathrm{Pt}, 0.5 \mathrm{wt} \% \mathrm{Fe}, 20 \mathrm{ppi}, 12 \% \rho$ metal foam from the front "end" piece (a) at the radial center (BSE image, scale: $\sim 1 \mathrm{~mm}$ ), and (b) at the radial edge (BSE image, scale: $\sim 1$ $\mathrm{mm})$.

Figure 6: X-ray energy map of a sectioned, virgin, 5 wt\% Pt, 0.5 wt $\%$ Fe, 20 ppi, $12 \% \rho$ metal foam from the front "end" piece at $2000 \mathrm{x}$ magnification.

Figure 7: SEM images of a sectioned, "used" $5 \mathrm{wt} \% \mathrm{Pt}, 0.5 \mathrm{wt} \% \mathrm{Fe}, 40 \mathrm{ppi}, 4 \% \rho$ metal foam from the (a) front "end" piece (BSE image, scale: $100 \mu \mathrm{m}$ ), (b) back "end" piece (SE image, scale: $100 \mu \mathrm{m}$ ), and (c) "middle" piece (BSE image, scale: $100 \mu \mathrm{m}$ ).

Figure 8: X-ray energy map of a $5 \mathrm{wt} \% \mathrm{Pt}, 0.5 \mathrm{wt} \% \mathrm{Fe}, 40 \mathrm{ppi}, 4 \% \rho$ metal foam at 500x magnification showing a continuous Al layer at the foamwashcoat interface.

Figure 9: SEM images of a $5 \mathrm{wt} \% \mathrm{Pt}, 0.5 \mathrm{wt} \% \mathrm{Fe}, 400 \mathrm{cpsi}$ ceramic straightchannel monolith from the front "end" piece at (a) 40x magnification (BSE image, scale: $\sim 1 \mathrm{~mm}$ ), and (b) 100x magnification (BSE image, scale: $\sim 500 \mu \mathrm{m})$.

Figure 10: Representative image of a ceramic monolith (porous, light color) with a catalyzed washcoat (grey color) [9].

Figure 11: X-ray energy map of a 5 wt $\%$ Pt, 0.5 wt $\%$ Fe, 400 cpsi ceramic straight-channel monolith cell corner from the front "end" piece at 700x magnification. 


\section{Background}

Previous work under this research grant focused on preferential oxidation (PROX) of carbon monoxide using various supports, such as ceramic straight-channel monoliths and metal foams. Foams are characterized by their pores per inch (ppi) and cell density ( $\rho$ ). Pores per inch is the number of pores in the foam per linear inch. Cell density is the ratio of the actual volume of the foam to its gross geometric volume. Monoliths are characterized by the number of cells per square inch (cpsi).

Four $5 \mathrm{wt} \% \mathrm{Pt}, 400 \mathrm{cpsi}$ ceramic straight-channel monolith catalysts were synthesized with different $\mathrm{Fe}$ loadings. The $\gamma-\mathrm{Al}_{2} \mathrm{O}_{3}$ washcoat loading was about $0.098 \mathrm{~g} / \mathrm{cm}^{3}$ of the gross support volume, and the $\mathrm{Pt}$ loading was $0.005 \mathrm{~g} \mathrm{Pt} / \mathrm{cm}^{3}$. At $100^{\circ} \mathrm{C}$ inlet temperature and using an adiabatic reactor, higher Fe loadings increased $\mathrm{CO}$ and $\mathrm{O}_{2}$ conversions and decreased CO selectivity for the PROX reaction $[1,2]$. At $170^{\circ} \mathrm{C}$, the conversions and selectivity were independent of Fe loading. This data was consistent with Korotkikh and Farrauto [3] under isothermal conditions.

Four metal foams, with a $5 \mathrm{wt} \% \mathrm{Pt} / 0.5 \mathrm{wt} \% \mathrm{Fe} / \gamma-\mathrm{Al}_{2} \mathrm{O}_{3}$ washcoat, were tested under various operating conditions for the PROX reaction [1]. The $40 \mathrm{ppi}, 4 \% \rho$ metal foam had the highest CO conversion and selectivity compared to the other three (20 ppi $4 \% \rho$, 20 ppi $12 \% \rho$, and 40 ppi $12 \% \rho$ ) metal foams. A comparison study was conducted on the $400 \mathrm{cpsi}$ ceramic monolith and the $40 \mathrm{ppi}, 4 \% \rho$ metal foam with a $5 \mathrm{wt} \% \mathrm{Pt} / 0.5$ wt $\% \mathrm{Fe} / \gamma-\mathrm{Al}_{2} \mathrm{O}_{3}$ washcoat. The $\mathrm{CO}$ conversion and selectivity of the metal foam were comparable to those of the ceramic monolith. Comparison tests at $80^{\circ} \mathrm{C}$ inlet temperature of a 400 cpsi equivalent metal monolith and a $20 \mathrm{ppi}, 11 \% \rho$ ceramic foam resulted in lower conversions and selectivity compared to the ceramic monolith and the metal foam.

Two important phenomena limit the PROX reaction: the reverse water-gas-shift (r-WGS) reaction, and transport resistances [1]. The r-WGS reaction was a significant side reaction under adiabatic conditions. This reaction made it impossible to achieve low outlet $\mathrm{CO}$ concentrations. A study of the individual effects of linear velocity and GHSV on $5.08 \mathrm{~cm}$ and $15.2 \mathrm{~cm}$ catalyst lengths revealed significant heat and mass transfer effects at low linear velocities. Both the r-WGS reaction and transport resistances must be overcome to reach low outlet $\mathrm{CO}$ concentrations.

Characterization techniques were used in an attempt to explain the differences in the activity and selectivity between the catalysts $[4,5]$. Pulse chemisorption and temperature programmed desorption (TPD) were used to quantify $\mathrm{CO}$ adsorption on the catalyst surface. Overall, the pulse chemisorption and TPD results did not describe the catalyst performance results. Higher $\mathrm{CO}$ adsorption on the catalyst surface did not correspond to higher CO conversions from the PROX reaction.

Initial scanning electron microscopy (SEM) images were taken on an uncatalysed, unwashcoated "blank" metal foam [5]. Cracks and holes observed on the "blank" foam were attributed to the heterogeneous metal deposition on the polyurethane foam template. Aluminum migration to the surface of the "blank" foam may promote adhesion between 
the $\mathrm{Al}_{2} \mathrm{O}_{3}$ washcoat and the foam. All of the work described in this section can be found in technical reports [6].

The focus of our most recent work is additional characterization of the PROX catalysts. Images were taken using a SEM to describe washcoat deposition. Catalyst cycling tests were conducted to simulate start-up thermal shocks and automotive mechanical vibration shocks.

\section{Scanning Electron Microscopy}

\subsection{Theory}

Scanning electron microscopy is a technique providing a highly magnified image of the surface of the material (from 10x - 300,000x). An electron gun is used to produce a source of primary electrons originating from a small spot. Details of the equipment are described elsewhere [5]. Schematics of the SEM machine operation and the electron optics are illustrated in Figure 1a and Figure 1b [7]. Samples must be grounded to discharge excess current from the primary electrons.

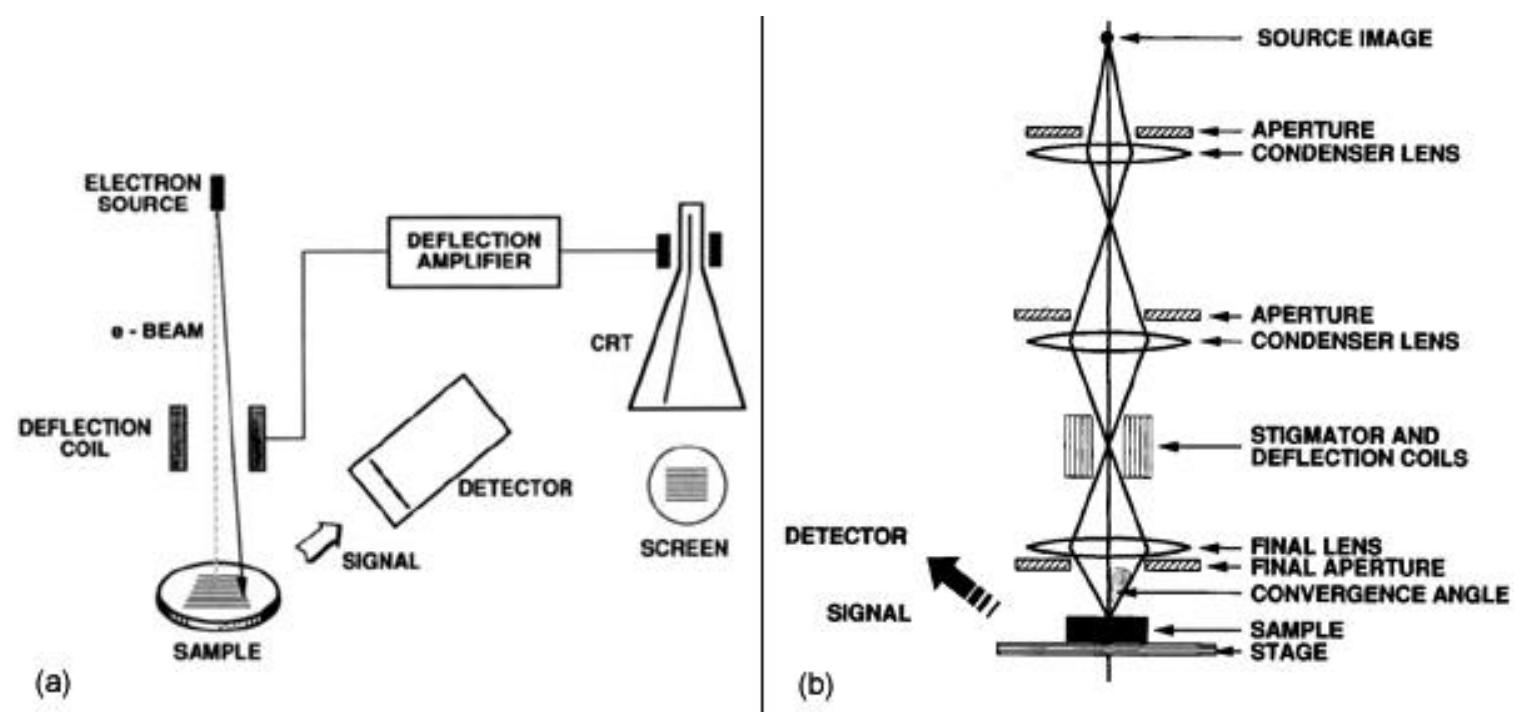

Figure 1: Schematic of the SEM (a) machine operation and (b) the electron optics [7].

There are three principle types of images that are generated using SEM: secondary electron (SE), backscattered electron (BSE), and elemental x-ray maps. Secondary electron and BSE are created by separate mechanisms, each with a distinct range of energies associated with the emitted electron. When the primary electron strikes an atom, it can either collide with an atomic electron (inelastic scattering), or circle the atomic nucleus and leave the atom (elastic scattering). Inelastic scattering occurs when the primary electron collides with an atomic electron, causing an energy transfer to the atomic electron. If the atomic electron has enough energy to exceed the work function of the material, it is ejected from the sample. An emitted electron with less than $\sim 50 \mathrm{eV}$ energy is called a SE. Elastic scattering occurs when the positive pull of the atomic 
nucleus causes the primary electron to orbit the nucleus, but the pull is not enough to keep it circling around the nucleus. The primary electron scatters, but there is no loss of kinetic energy. When this type of electron exits the sample with energy greater than $\sim 50$ $\mathrm{eV}$, it is called a BSE. Higher atomic number materials have a higher likelihood for a BSE emission. This effect creates a built-in contrast in a BSE image caused by elemental differences [7].

In addition to electron-electron interactions, the primary electron can collide and eject a core electron from the atom, in a process called photoionization. The excited atom will decay to its ground state by emitting either a x-ray photon or an Auger electron [7]. The $\mathrm{x}$-ray photon is characteristic to each element, and can be separated by energy using an energy dispersive $x$-ray detector or by wavelength using a wavelength spectrometer. The SEM can interpret these signals to create an elemental mapping of the sample. The spatial resolution of these images is at best $\sim 5 \mu \mathrm{m}$. X-ray photon energies for relevant elements are listed in Table 1.

Table 1: X-ray photon energies for relevant elements.

\begin{tabular}{|c|c|c|c|c|c|c|c|}
\hline \multirow{2}{*}{} & \multicolumn{7}{c|}{ X-ray Photon Energies (keV) } \\
\cline { 2 - 8 } \multicolumn{2}{|c|}{} & \multicolumn{2}{c|}{ K Transitions } & \multicolumn{2}{c|}{ L Transitions } & \multicolumn{2}{c|}{ M Transitions } \\
\hline Atomic Number & Element & $\mathrm{K}_{\alpha}$ & $\mathrm{K}_{\beta}$ & $\mathrm{L}_{\mathrm{L}}$ & $\mathrm{L}_{\alpha}$ & $\mathrm{M}_{\mathrm{Z}}$ & $\mathrm{M}_{\alpha}$ \\
\hline 6 & $\mathrm{C}$ & 0.28 & -- & -- & -- & -- & -- \\
\hline 8 & $\mathrm{O}$ & 0.53 & -- & -- & -- & -- & -- \\
\hline 12 & $\mathrm{Mg}$ & 1.25 & 1.30 & -- & -- & -- & -- \\
\hline 13 & $\mathrm{Al}$ & 1.49 & 1.55 & -- & -- & -- & -- \\
\hline 16 & $\mathrm{~S}$ & 2.31 & 2.46 & 0.15 & -- & -- & -- \\
\hline 17 & $\mathrm{Cl}$ & 2.62 & 2.82 & 0.18 & -- & -- & -- \\
\hline 24 & $\mathrm{Cr}$ & 5.41 & 5.95 & 0.50 & 0.57 & -- & -- \\
\hline 26 & $\mathrm{Fe}$ & 6.40 & 7.06 & 0.62 & 0.71 & -- & -- \\
\hline 39 & $\mathrm{Y}$ & 14.93 & 16.77 & 1.69 & 1.92 & 0.13 & -- \\
\hline 46 & $\mathrm{Pd}$ & 21.18 & 23.87 & 2.50 & 2.84 & 0.29 & -- \\
\hline 56 & $\mathrm{Ba}$ & 32.19 & 36.47 & 3.95 & 4.46 & 0.60 & -- \\
\hline 78 & $\mathrm{Pt}$ & 66.83 & 75.87 & 8.27 & 9.44 & 1.60 & 2.05 \\
\hline 79 & $\mathrm{Au}$ & 68.80 & 78.10 & 8.49 & 9.71 & 1.66 & 2.12 \\
\hline
\end{tabular}

\subsection{Catalysed Supports: Preparation Procedure}

Prior to performing SEM on some of the catalysed supports, they were cut into 3 pieces. Sectioning the catalysts into three pieces ( 2 "end" pieces and one "middle" piece) allow us to observe any changes in the washcoat in both the radial and axial direction. A schematic of the sectioning is illustrated in Figure 2. The SEM catalyst preparation procedure is described elsewhere [5]. Briefly, the supports were mounted in epoxy, sectioned using an abrasive cutter, and polished multiple times. The samples were then sputtered with an Au-Pd coating and pasted with colloidal graphite. 


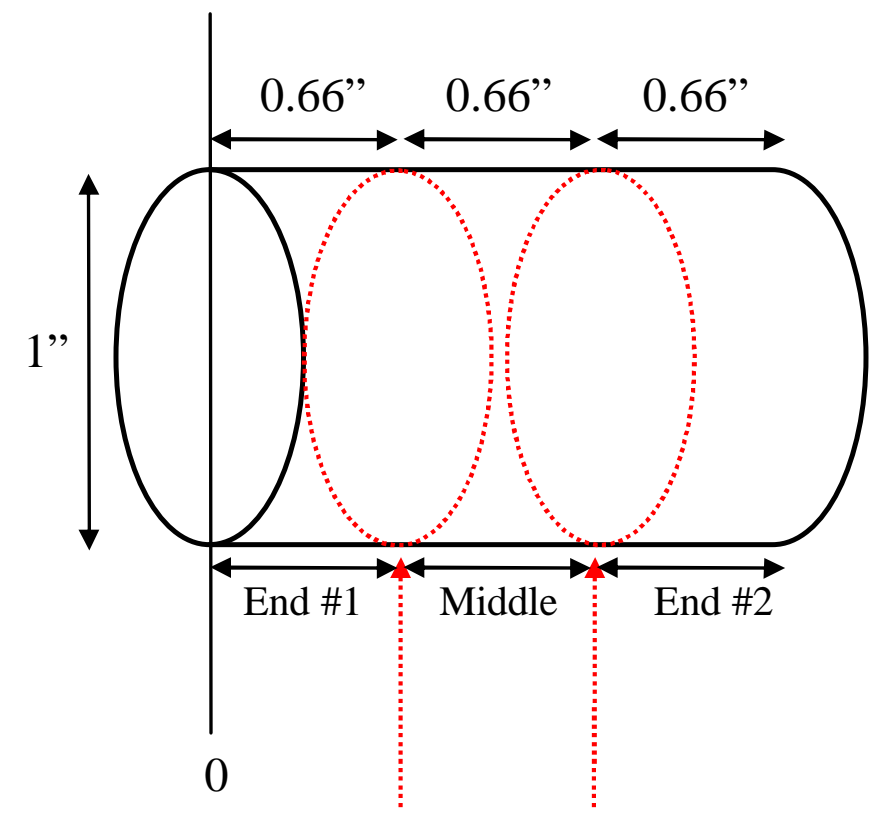

Cut at these points

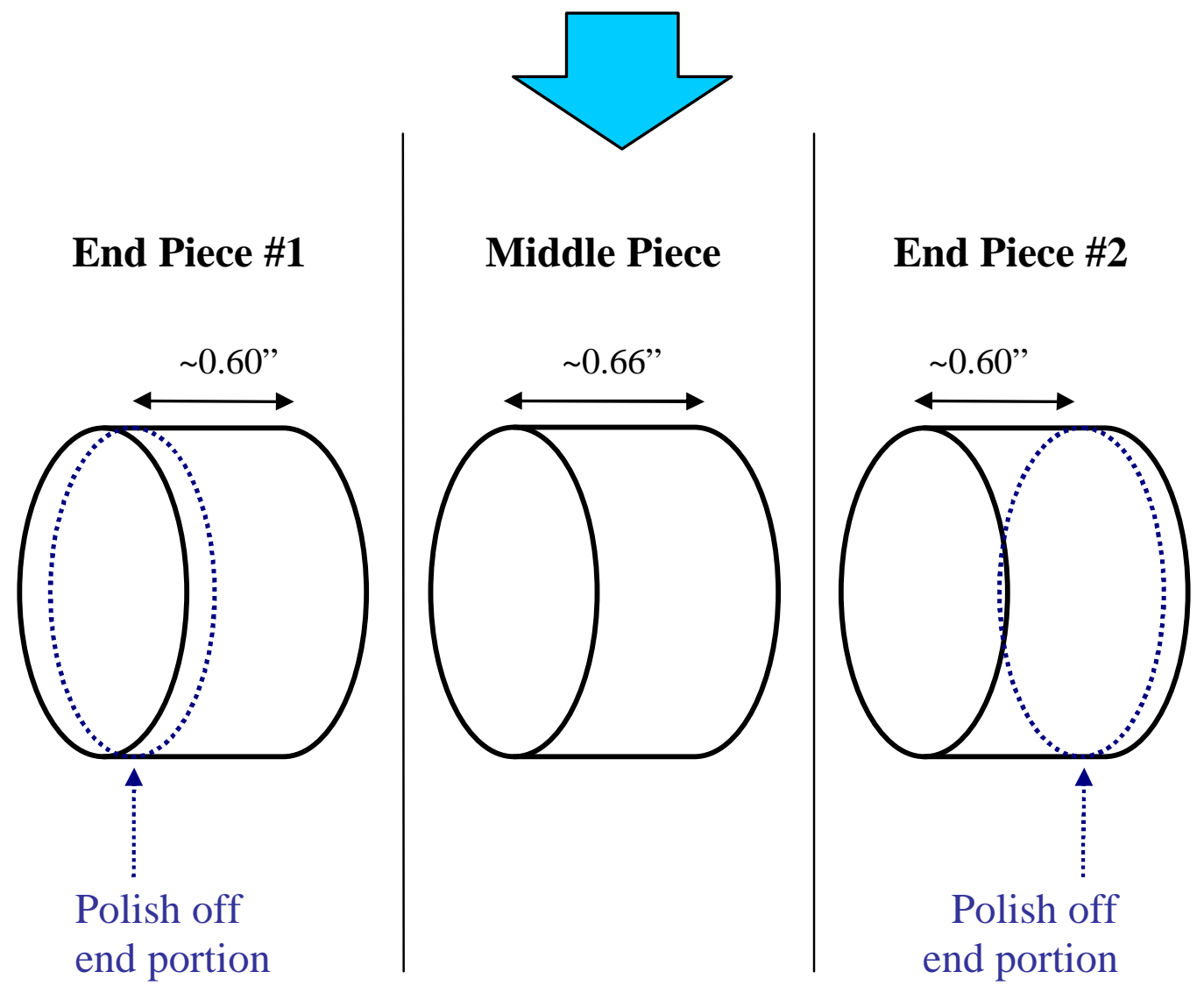

Figure 2: Schematic describing the sectioning of the supports into three pieces: 2 "end" pieces and one "middle" piece. 


\section{3 "Used" 20 ppi, $12 \% \rho$ Metal Foam Images}

Some of the SEM images taken in the following sections were from a Hitachi S3200 Variable Pressure Environmental SEM (ESEM) located at NC State's Analytical Instrumentation Facility in Raleigh, NC. The ESEM has an Oxford Isis EDS system attachment, allowing for elemental analysis of Boron and above. In addition, an Amray SEM machine with EDS capability at the Selee Corporation in Hendersonville, NC, was used to capture images.

Figure 3a shows an image of a "used" $5 \mathrm{wt} \% \mathrm{Pt}, 0.5 \mathrm{wt} \% \mathrm{Fe}, 20 \mathrm{ppi}, 12 \% \rho$ metal foam prior to sectioning. The image is of an $\mathrm{Al}_{2} \mathrm{O}_{3}$-washcoated, catalysed strut. When 4 or 5 different struts converge at one location, a ligament is formed. From Figure $3 \mathrm{a}$, a porous washcoat is seen. Previous images from an uncatalysed, unwashcoated "blank" metal foam showed a different structure filled with cracks and holes on the metal surface [5].

Figure $3 \mathrm{~b}$ shows a magnified SEM image of just the catalysed washcoat. Alumina has a microporous structure, with a higher surface area $\left(\sim 140 \mathrm{~m}^{2} / \mathrm{gr}\right.$, or $\sim 2.8 \times 10^{8} \mathrm{~m}^{2} / \mathrm{m}^{3}$ assuming an $\mathrm{Al}_{2} \mathrm{O}_{3}$ density of $\left.2.0 \mathrm{gr} / \mathrm{cm}^{3}\right)$ than a metal foam $\left(\sim 2.5 \times 10^{3} \mathrm{~m}^{2} / \mathrm{m}^{3}\right)$. Alumina increases the surface area for Pt and Fe catalyst deposition.

Figure 4 shows SEM images of two "end" pieces (a \& b) and one "middle" piece (c) of the sectioned, "used" 20 ppi, $12 \% \rho$ metal foam. The images reveal that the washcoat is inconsistent throughout the foam; not all of the struts and ligaments contain washcoat. The washcoat deposition is more inconsistent on the two "end" pieces (Figure 4a \& b) than on the "middle" piece (Figure 4c). Moreover, the washcoat thickness varies between each section of the foam, both in the radial and axial direction. The calculated washcoat thickness for a $20 \mathrm{ppi}, 12 \% \rho$ metal foam is $\sim 25 \mu \mathrm{m}$ (assuming a washcoat loading of $0.098 \mathrm{gr} / \mathrm{cm}^{3}$ of the gross support volume, a dry washcoat density of 2.0 $\mathrm{gr} / \mathrm{cm}^{3}$, and a surface area per unit volume of $\left.2.0 \mathrm{~mm}^{-1}[8]\right)$. The averaged values of the actual washcoat thickness from SEM images range from $\sim 25-120 \mu \mathrm{m}$. Therefore, the SEM pictures expose a heterogeneous washcoat thickness and an inconsistent washcoat deposition.

There are three possible explanations for the inconsistent washcoat deposition. One is the washcoat deposition technique. It is difficult to deposit washcoat on all of the struts and ligaments in the metal foam since the porosity of the metal foam surface is low, causing poor and inconsistent adhesion between the washcoat and the foam. Secondly, some of the washcoat fell off during the PROX reaction studies. This is confirmed from washcoat found in the reactor and collected in the $7 \mu \mathrm{m}$ particle filter downstream of the reactor. Thirdly, some of the washcoat may have been damaged by the abrasive cutter during sectioning. 

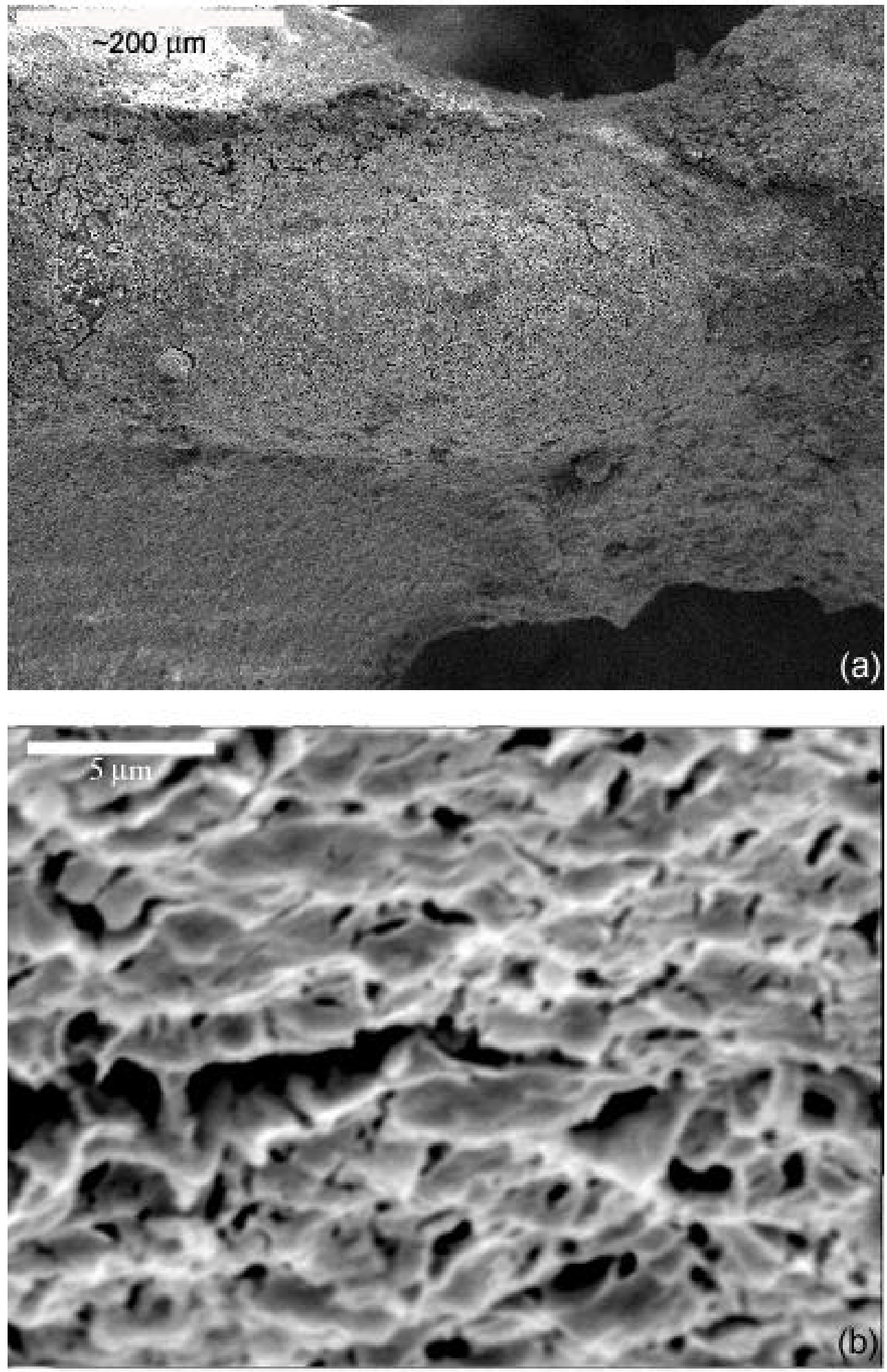

Figure 3: SEM images of a "used" $5 \mathrm{wt} \% \mathrm{Pt}, 0.5 \mathrm{wt} \% \mathrm{Fe}, 20 \mathrm{ppi}, 12 \% \rho$ metal foam (a) strut (SE image, scale: $200 \mu \mathrm{m}$ ) and (b) the strut at 10,000x (SE image, scale: $5 \mu \mathrm{m}$ ) 

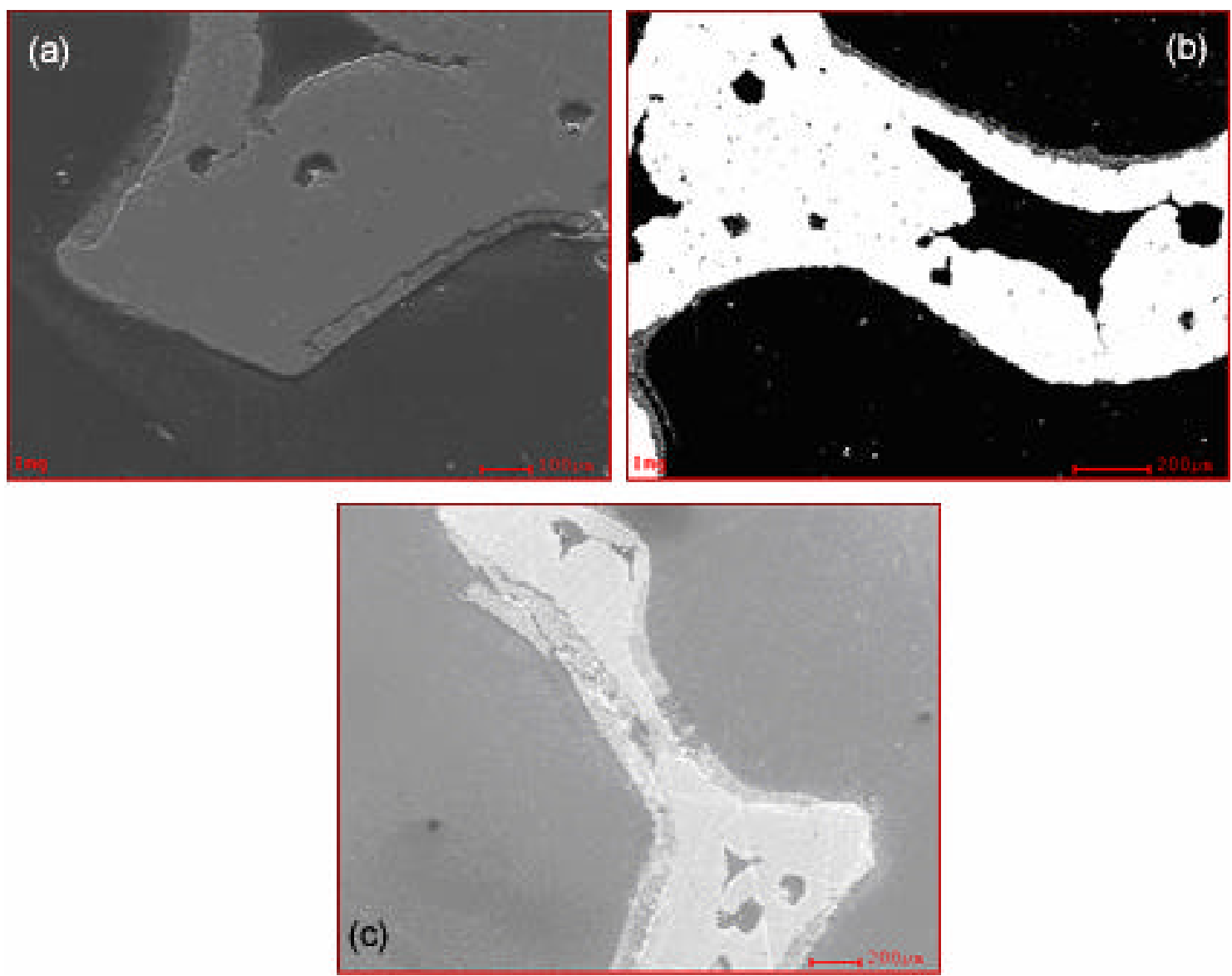

Figure 4: SEM images of a sectioned, "used" 5 wt $\%$ Pt, 0.5 wt $\%$ Fe, 20 ppi, $12 \% \rho$ metal foam from the (a) front "end" piece (SE image, scale: $100 \mu \mathrm{m}$ ), (b) back "end" piece (BSE image, scale: $200 \mu \mathrm{m}$ ), and (c) "middle" piece (SE image, scale: $200 \mu \mathrm{m}$ ).

\section{4 "Virgin" 20 ppi, 12\% $\rho$ Metal Foam Images}

One of the explanations for inconsistent washcoat deposition described above is washcoat damage during PROX reaction studies. Further investigation was conducted by taking SEM images of a virgin (i.e. untested) $5 \mathrm{wt} \% \mathrm{Pt}, 0.5 \mathrm{wt} \% \mathrm{Fe}, 20 \mathrm{ppi} 12 \% \rho$ metal foam. If this concern is valid, then a virgin metal foam will have a more homogeneous washcoat thickness and more consistent washcoat deposition than a "used" one.

Figure 5 shows representative images of the virgin metal foam. The calculated washcoat thickness for a $20 \mathrm{ppi}, 12 \% \rho$ metal foam is $\sim 25 \mu \mathrm{m}$ (assuming a surface area per unit volume of $\left.2.0 \mathrm{~mm}^{-1}[8]\right)$. The averaged values of the actual washcoat thickness from SEM images range from $\sim 15-90 \mu \mathrm{m}$. This is a smaller range compared to the "used" metal foam, but is still a large deviation from the calculated average value. Qualitatively, there are no distinct differences between the virgin and "used" metal foams. Both the virgin and "used" foams have a heterogeneous washcoat thickness, although there may be less unwashcoated area on the virgin foam. Both foams have cracks and discontinuity in the washcoat. This washcoat shearing probably occurred during sectioning by the abrasive cutter, and not during the PROX studies. 
Figure 6 shows an x-ray mapping of an $\mathrm{Al}_{2} \mathrm{O}_{3}$ washcoat layer on the sectioned 20 ppi, $12 \% \rho$ metal foam. The carbon $(\mathrm{CKa})$ and chlorine $(\mathrm{ClKa}) \mathrm{K}_{\alpha}$ edge energies are from the epoxy. The presence of $\mathrm{Fe}(\mathrm{FeKa})$ catalyst in the washcoat is not detected through the background scatter. This is expected because the Oxford Isis EDS attachment has a minimum detection limit of $\sim 1 \%$, well above the nominal $0.5 \mathrm{wt} \%$ Fe loading. The $\mathrm{Pt}$ map (PtMa1) shows small Pt clusters above the background level. The $\mathrm{Cr}$ map (CrKa) indicates some minor spots above the background. This may be caused by $\mathrm{Cr}$ migration from the FeCrAlY metal foam during calcination.

Interestingly, $\mathrm{Ba}(\mathrm{BaLa})$ and $\mathrm{S}(\mathrm{SKa})$ are detected in the washcoat. The stronger thermal intensities in the $\mathrm{Ba}$ and $\mathrm{S}$ maps nearly overlap each other. Moreover, the $\mathrm{O}$ map $(\mathrm{OKa})$ has a slightly stronger intensity where the $\mathrm{Ba}$ and $\mathrm{S}$ are located. These strong $\mathrm{Ba}$, $\mathrm{S}$, and $\mathrm{O}$ intensities, most likely the compound $\mathrm{BaSO}_{4}$, overlap the white spots on the topleft BSE image. One reason for the presence of $\mathrm{BaSO}_{4}$ is that this compound is sometimes added during the washcoating process to provide thermal stability at higher temperatures.

\section{5 "Used" 40 ppi, $4 \% \rho$ Metal Foam Images}

A similar analysis was conducted on the $5 \mathrm{wt} \% \mathrm{Pt}, 0.5 \mathrm{wt} \% \mathrm{Fe}, 40 \mathrm{ppi}, 4 \% \rho$ metal foam. Figure 7 shows images of two "end" pieces (a \& b) and one "middle" piece (c) of the sectioned, "used" metal foam. Similar to the "used" $20 \mathrm{ppi}, 12 \% \rho$ metal foam, the images reveal a heterogeneous washcoat. In Figure 7a, there is much more washcoat on the top side $(\sim 50 \mu \mathrm{m})$ than the left side $(\sim 10 \mu \mathrm{m})$. The calculated washcoat thickness for a $40 \mathrm{ppi}, 4 \% \rho$ metal foam is $\sim 20 \mu \mathrm{m}$ (assuming a surface area per unit volume of 2.5 $\left.\mathrm{mm}^{-1}[8]\right)$. The averaged values of the actual washcoat thickness from SEM images range from $\sim 10-95 \mu \mathrm{m}$. This is a smaller range than the $20 \mathrm{ppi}, 12 \% \rho$ metal foam, but still significantly different from the calculated value. Moreover, there are struts and ligaments without washcoat. For example, in Figure 7c there is no washcoat (spotted grey area) on the left-hand side of the metal foam (white area). No major differences were seen between the 40 ppi $4 \% \rho$ and the 20 ppi $12 \% \rho$ metal foams.

The $40 \mathrm{ppi}$, $4 \% \rho$ metal foam seen in the top-left image (Img) of Figure 8 shows a distinct, thin $\gamma-\mathrm{Al}_{2} \mathrm{O}_{3}$ washcoat layer on top of the thick metal foam. The x-ray map in Figure 8 reveals a brighter intensity of $\mathrm{Al} \mathrm{K}_{\alpha} \mathrm{X}$-ray energy $(\mathrm{AlK})$ at the foam-washcoat interface. This Al-rich area at the border supports the hypothesis that Al in the metal foam migrates to the surface during the calcination step.

Also seen in Figure 8 is the $\mathrm{x}$-ray map for $\mathrm{Ba}(\mathrm{BaL})$. Barium is mainly detected in the washcoat. Similarly to the virgin $20 \mathrm{ppi}, 12 \% \rho$ metal foam, it is possible that $\mathrm{BaSO}_{4}$ is inserted in the washcoat for thermal stability. The $\mathrm{S}$ and $\mathrm{O}$ x-ray energies were not measured. Iron $(\mathrm{FeK})$ and $\mathrm{Cr}(\mathrm{CrK})$ are metals that comprise the foam. No discernable presence of $\mathrm{Na}(\mathrm{NaK})$ and $\mathrm{Cl}(\mathrm{ClK})$ are detected above the background scatter. No significant extent of $\mathrm{Pt}(\mathrm{PtL})$ and Fe catalysts are detected in the washcoat, possibly because of their low concentrations. 

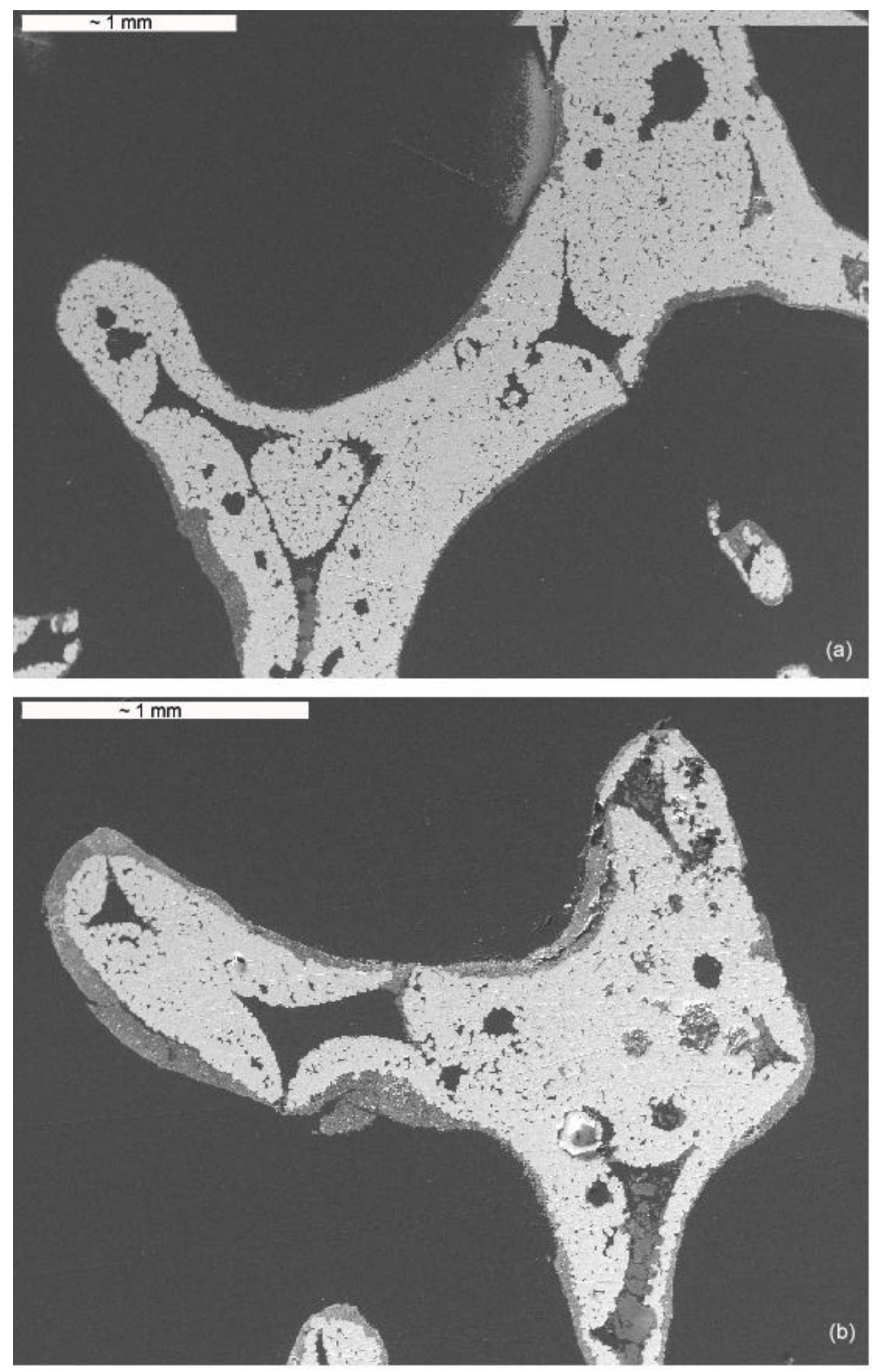

Figure 5: SEM images of a sectioned, virgin, $5 \mathrm{wt} \% \mathrm{Pt}, 0.5 \mathrm{wt} \% \mathrm{Fe}, 20 \mathrm{ppi}, 12 \% \rho$ metal foam from the front "end" piece (a) at the radial center (BSE image, scale: $\sim 1$ $\mathrm{mm}$ ), and (b) at the radial edge (BSE image, scale: $\sim 1 \mathrm{~mm}$ ). 


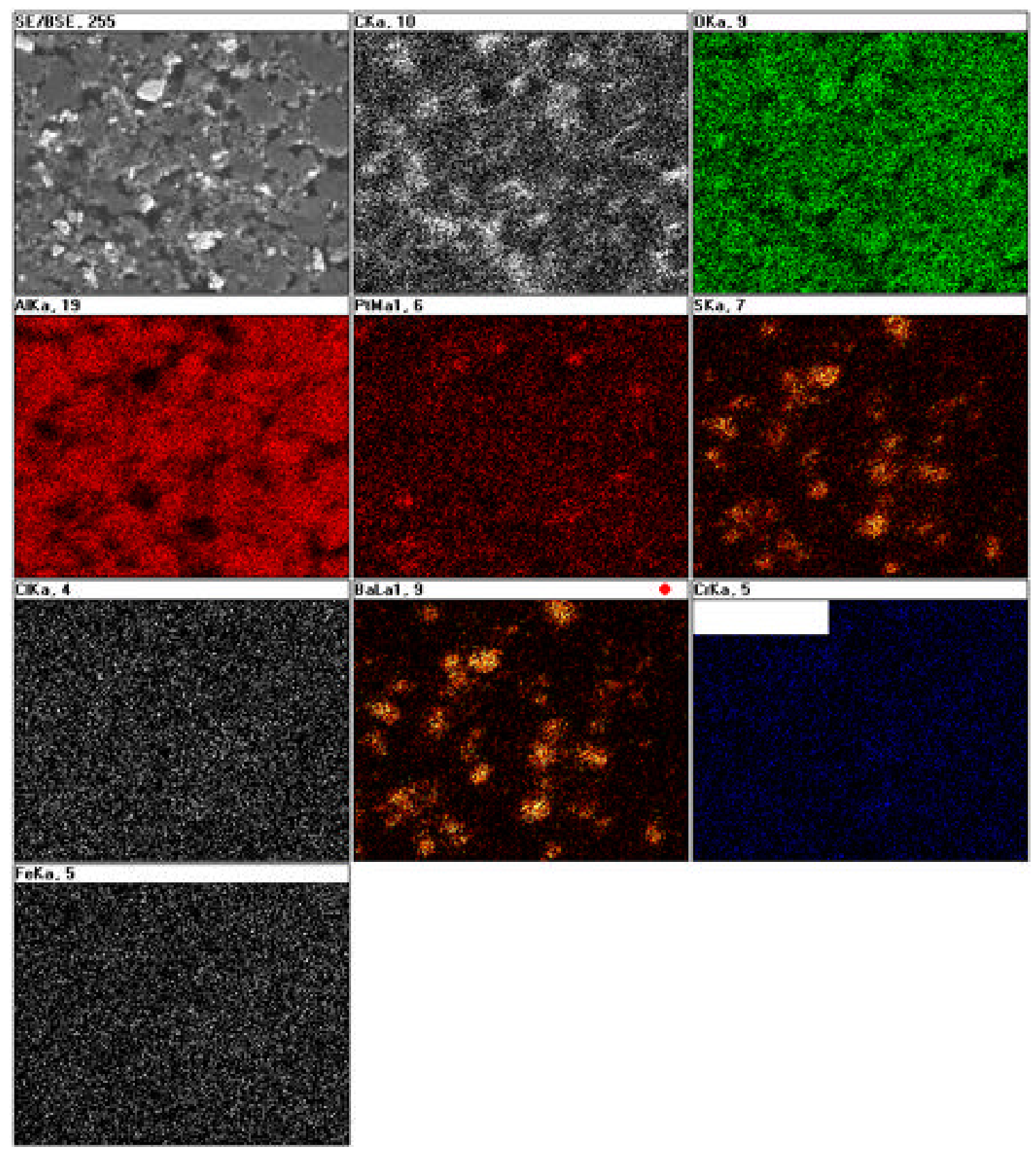

Figure 6: X-ray energy map of a sectioned, virgin, 5 wt $\% \mathrm{Pt}, 0.5 \mathrm{wt} \% \mathrm{Fe}, 20 \mathrm{ppi}, 12 \% \rho$ metal foam from the front "end" piece at 2000x magnification. 

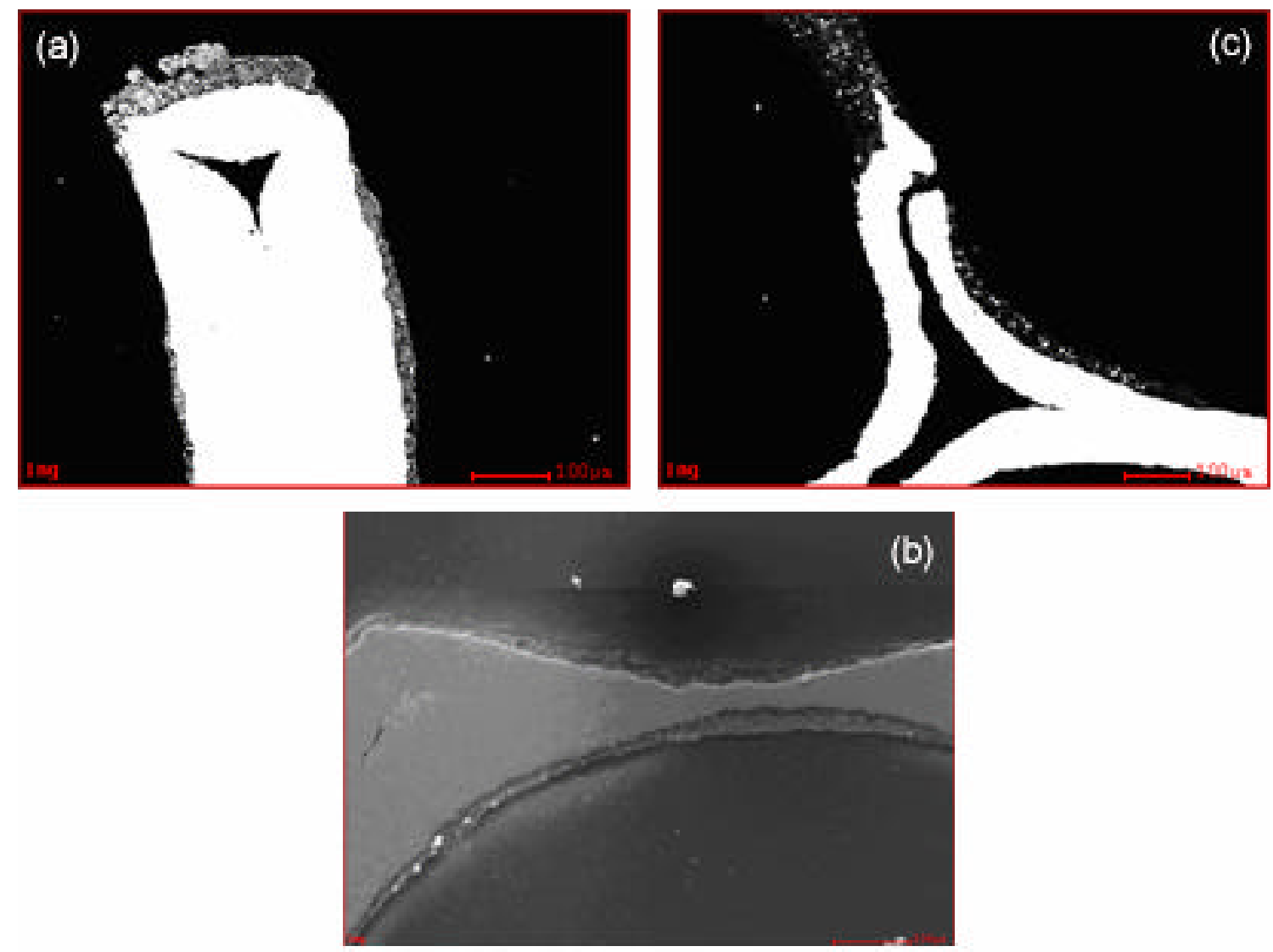

Figure 7: SEM images of a sectioned, "used" $5 \mathrm{wt} \% \mathrm{Pt}, 0.5 \mathrm{wt} \% \mathrm{Fe}, 40 \mathrm{ppi}, 4 \% \rho$ metal foam from the (a) front "end" piece (BSE image, scale: $100 \mu \mathrm{m}$ ), (b) back "end" piece (SE image, scale: $100 \mu \mathrm{m}$ ), and (c) "middle" piece (BSE image, scale: $100 \mu \mathrm{m}$ ).

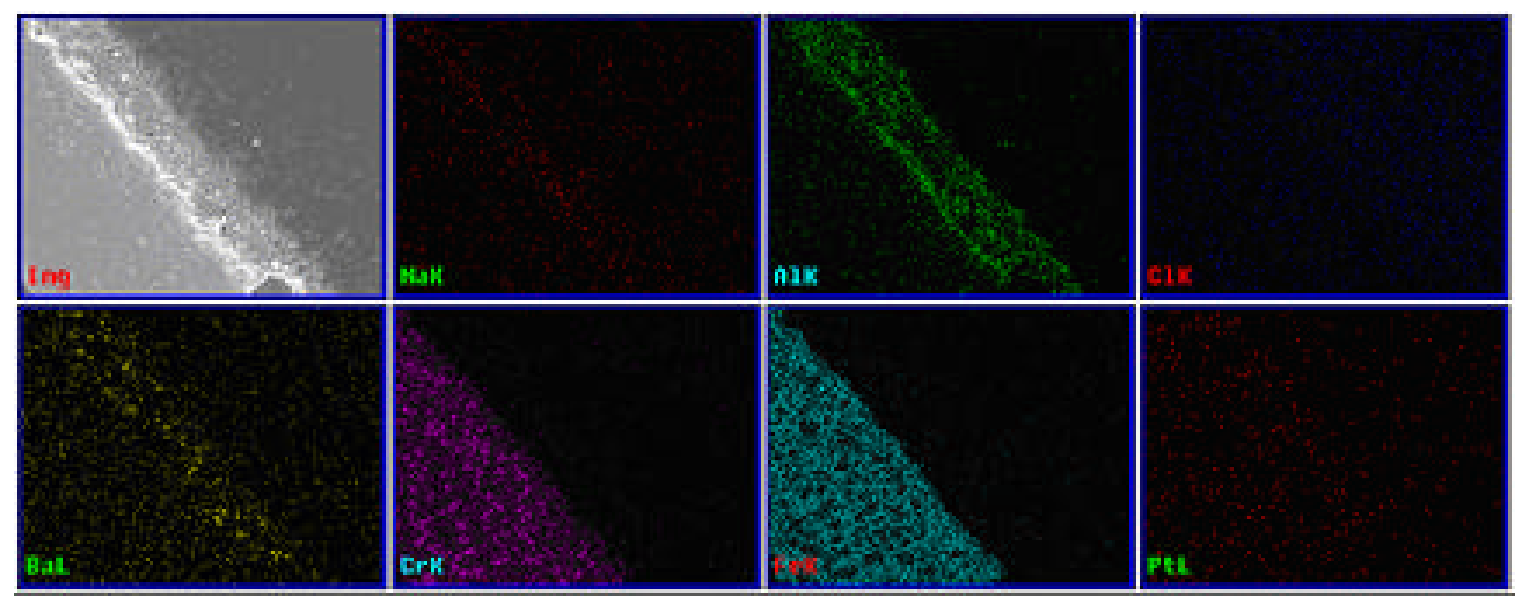

Figure 8: X-ray energy map of a $5 \mathrm{wt} \% \mathrm{Pt}, 0.5 \mathrm{wt} \% \mathrm{Fe}, 40 \mathrm{ppi}, 4 \% \rho$ metal foam at 500x magnification showing a continuous $\mathrm{Al}$ layer at the foam-washcoat interface. 


\section{6 “Used" 400 cpsi Ceramic Straight-Channel Monolith Images}

Scanning electron microscopy images of a honeycomb monolith were taken to determine if the washcoat thickness and deposition were as heterogeneous as on the metal foams. Figure 9 shows two images of a front "end" piece of a "used" $5 \mathrm{wt} \% \mathrm{Pt}, 0.5 \mathrm{wt} \% \mathrm{Fe}, 400$ cpsi ceramic straight-channel monolith. A number of cracks and defects are seen on the washcoat. One explanation for these defects is damage during the PROX reaction studies. Alternatively, the abrasive cutter may have damaged the washcoat during sectioning.

The calculated washcoat thickness for a $400 \mathrm{cpsi}$ ceramic monolith is $\sim 15-20 \mu \mathrm{m}$ (assuming a surface area per unit volume of $2.8 \mathrm{~mm}^{-1}$ [9]). The averaged values of the actual washcoat thickness from SEM images range from $\sim 25-120 \mu \mathrm{m}$. The averaged values of the actual washcoat thickness along the walls (i.e., not including the cell corners) from SEM images vary from $\sim 10-30 \mu \mathrm{m}$, with a standard deviation of 3-15 $\mu \mathrm{m}$. The averaged values of the actual washcoat thickness along the cell corners from SEM images range from $\sim 40-70 \mu \mathrm{m}$, with a standard deviation of 25-40 $\mu \mathrm{m}$. The maximum cell corner washcoat thickness ranges from 100-160 $\mu \mathrm{m}$. Cell corners have a higher washcoat thickness because of higher surface tension along the cell corners compared to the cell wall. The higher surface tension increases the amount of washcoat deposited on the corners. The washcoat deposition on the ceramic monolith is consistent with typical results. For comparison, Figure 10 is a representative picture of a washcoated ceramic monolith from "Catalytic Air Pollution Control: Commercial Technology" by Heck et al. [9].

The washcoat thickness on the monolith is more uniform than on the metal foam. One reason is that honeycomb monoliths are more structured than porous foams. These monoliths have straight channels, making it easier to deposit washcoat homogeneously. Additionally, the technology of washcoating ceramic monoliths is well developed and has been practiced for over 40 years. In contrast, the structure of foams is more irregular, and the washcoating process is less mature. Metal foams have more variation in surface tension, which may account for the uneven washcoat deposition. Straight-channel monoliths have only two major variations in surface tension: along the cell corners and the cell walls. Therefore, it makes sense that the metal foams have a larger range in washcoat thickness than the ceramic monoliths. 

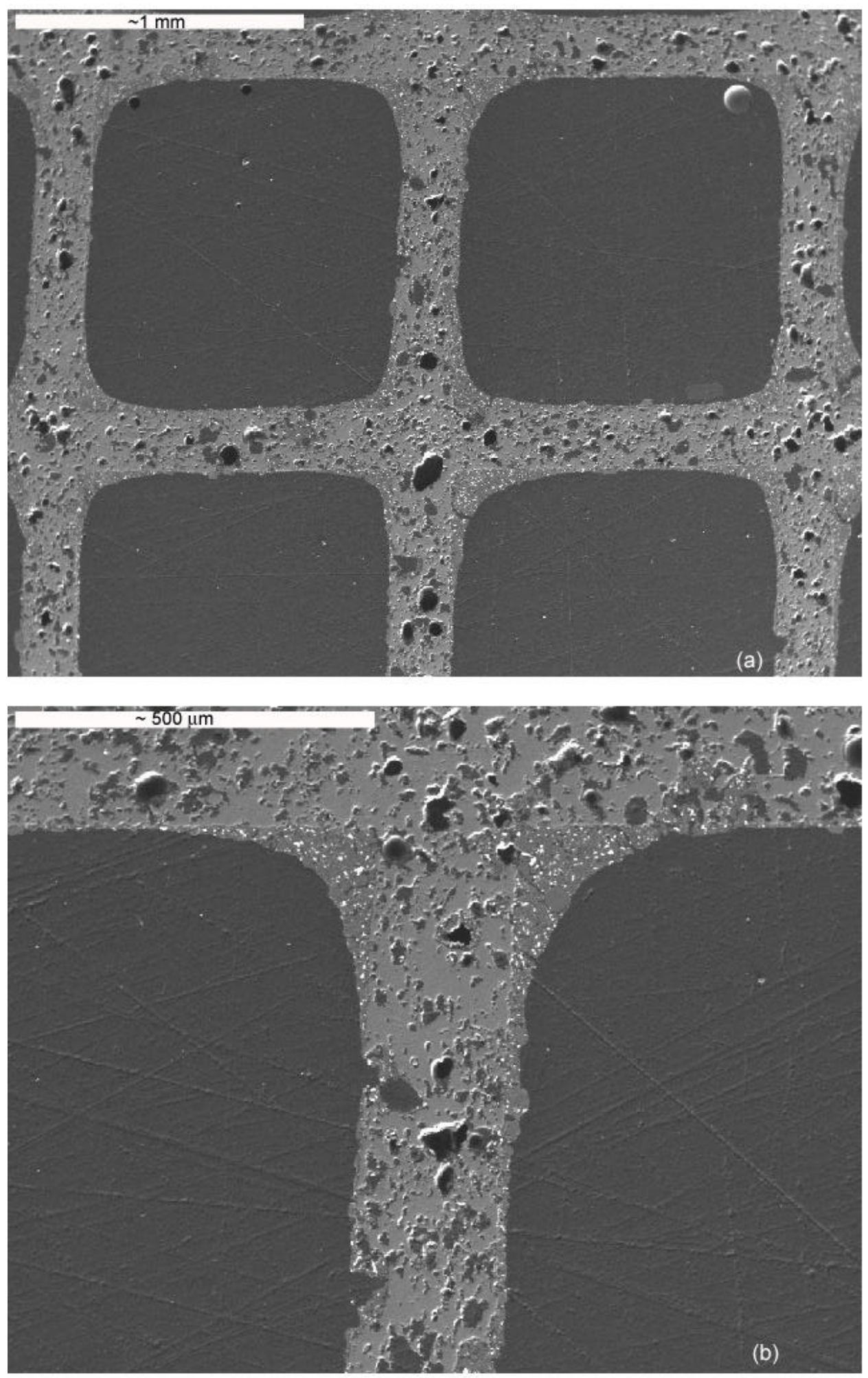

Figure 9: SEM images of a $5 \mathrm{wt} \% \mathrm{Pt}, 0.5 \mathrm{wt} \% \mathrm{Fe}, 400 \mathrm{cpsi}$ ceramic straight-channel monolith from the front "end" piece at (a) 40x magnification (BSE image, scale: 1 $\mathrm{mm}$ ), and (b) 100x magnification (BSE image, scale: $\sim 500 \mu \mathrm{m}$ ). 


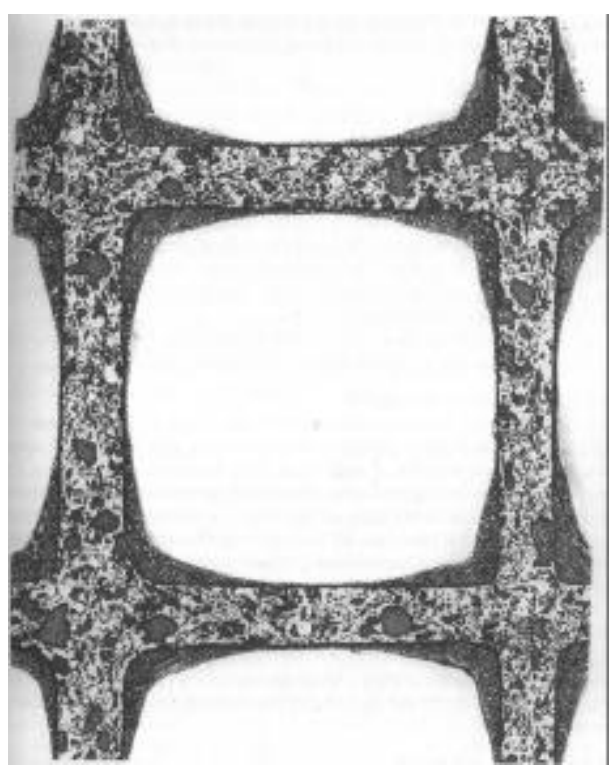

Figure 10: Representative image of a ceramic monolith (porous, light color) with a catalyzed washcoat (grey color) [9].

Figure 11 is an EDS mapping of a cell corner of a PROX catalyst prepared on a ceramic monolith. The magnesium (MgKa1) and silicon ( $\mathrm{SiKa}) \mathrm{K}_{\alpha}$ edge energies are from the cordierite monolith $\left(2 \mathrm{MgO}-2 \mathrm{Al}_{2} \mathrm{O}_{3}-5 \mathrm{SiO}_{2}\right)$. The $\mathrm{Al}(\mathrm{AlKa})$ and $\mathrm{O}(\mathrm{OKa})$ are present in both the cordierite and the washcoat. The $\mathrm{C}(\mathrm{CKa})$ and $\mathrm{Cl}(\mathrm{ClKa})$ are from the epoxy. The Pt (PtMa1) $\mathrm{M}_{\alpha}$ energy map shows dispersed $\mathrm{Pt}$ in the washcoat above the background scatter. The presence of low concentrations of $\mathrm{Fe}(\mathrm{FeKa})$ catalyst in the washcoat is not detected through the background. Finally, Ba (BaLa1) and S (SKa) are detected in the washcoat. Similar to the EDS maps of the "used" and virgin metal foams, $\mathrm{BaSO}_{4}$ may have been incorporated into the washcoat for thermal stability. 


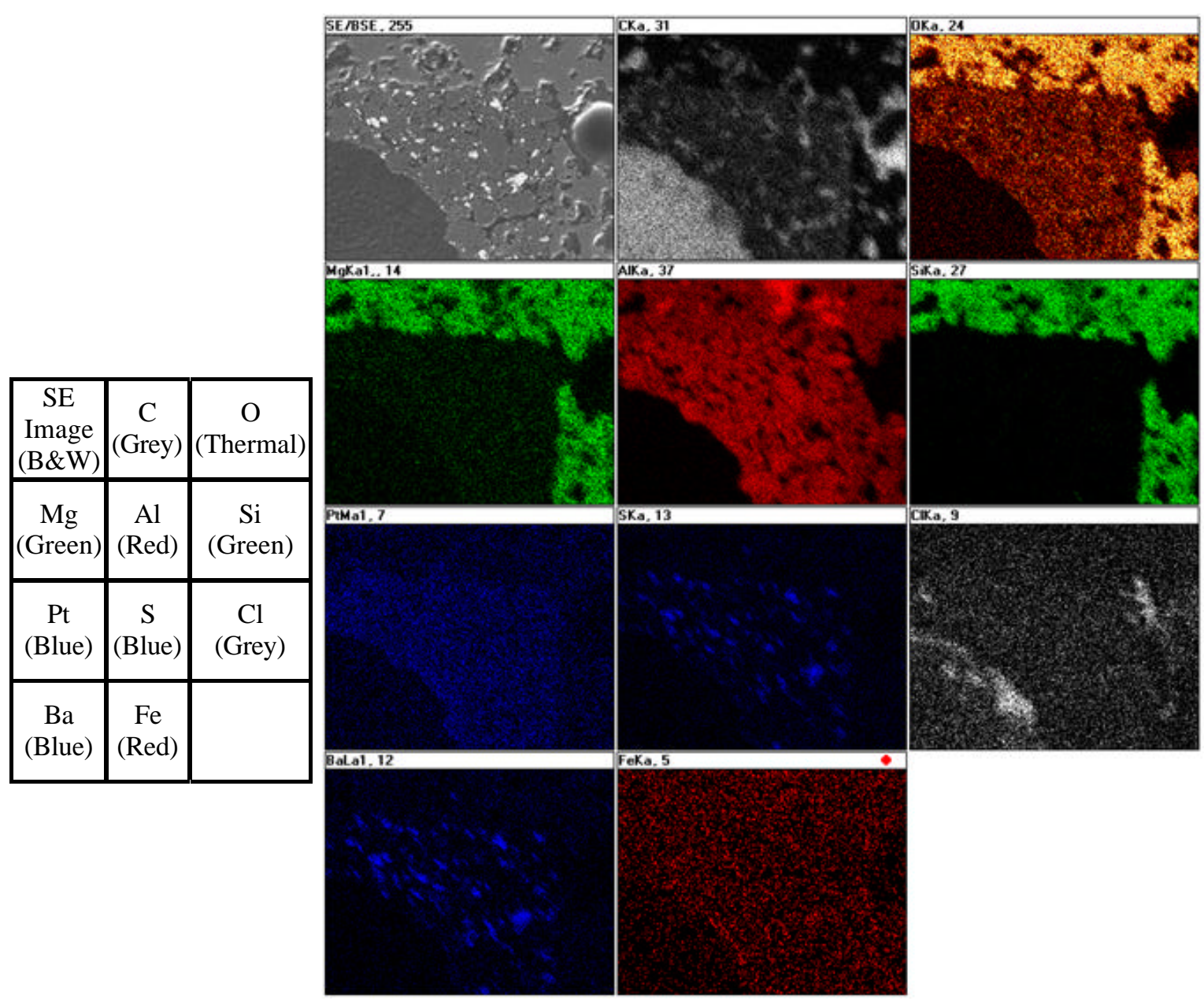

Figure 11: X-ray energy map of a $5 \mathrm{wt} \% \mathrm{Pt}, 0.5 \mathrm{wt} \% \mathrm{Fe}, 400$ cpsi ceramic straightchannel monolith cell corner from the front "end" piece at 700x magnification.

\section{Catalyst (Thermal and Mechanical) Cycling}

\subsection{Mechanical Cycling}

Mechanical cycling experiments were conducted to test the adhesion of the washcoat. A $0.5 \mathrm{wt} \% \mathrm{Pt}, 0.005 \mathrm{wt} \% \mathrm{Fe}, 20 \mathrm{ppi}, 12 \% \rho$ metal foam was completely submerged in a Branson Model 8210 Sonicator filled with water. The sonicator operates at $40 \mathrm{kHz}$ frequency, causing cavitations and implosions within the sonicator tank. This creates strong mechanical vibrations on the metal foam, potentially causing washcoat loss.

The metal foam was placed in a plastic bag to collect any lost washcoat. The plastic bag was put in a small jar (roughly the size of the metal foam) to prevent any lost washcoat from falling into the sonicator in case the bag broke. The jar was filled with water to allow energy transfer from the implosions outside the jar to the plastic bag inside the jar.

Over a period of 7 days, the metal foam was sonicated for $\sim 43$ hours. At the end of each day, the metal foam was weighed to quantify any washcoat loss. No appreciable 
washcoat loss was observed after 7 days of mechanical cycling. The catalyst weight change was negligible $(<0.001$ grams or $<0.04 \%$ weight change). A visual check confirmed that there was no washcoat in the plastic bag. Therefore, the sonication technique for mechanical cycling caused little to no washcoat loss.

\subsection{Thermal Cycling}

Thermal cycling tests were conducted on another $0.5 \mathrm{wt} \% \mathrm{Pt}, 0.005 \mathrm{wt} \% \mathrm{Fe}, 20 \mathrm{ppi}, 12 \%$ $\rho$ metal foam. Thermal shocks to a catalysed support may cause washcoat delamination from the support [9], especially during startup (lightoff) and shutdown. This effect is caused by differences in the coefficient of thermal expansion. A Barnstead Model $1315 \mathrm{M}$ Furnace was used to ramp the metal foam to multiple temperatures. The furnace setpoints were: $100^{\circ} \mathrm{C}, 150^{\circ} \mathrm{C}, 200^{\circ} \mathrm{C}, 250^{\circ} \mathrm{C}, 300^{\circ} \mathrm{C}$, and $350^{\circ} \mathrm{C}$. The temperature was held for 30 minutes at each setpoint before increasing to the next setpoint. At $350^{\circ} \mathrm{C}$, the temperature was held for 60 minutes. The metal foam was then removed from the furnace to the ambient air to cool down. The furnace ramp rate was roughly $10^{\circ} \mathrm{C} / \mathrm{min}$. A porcelain dish was placed beneath the metal foam to collect any fallen washcoat. The metal foam was weighed before and after each cycle to quantify any washcoat loss.

The metal foam was tested for 3 days, with one cycle per day. Weight loss was observed at the end of each cycle, but this was attributed to water evaporation from the metal foam. For example, after one cycle the metal foam was left overnight in ambient air and reweighed at the start of the next cycle. The metal foam gained enough weight to reach its original weight prior to any cycling. The overall weight loss was small ( $\sim 0.02$ grams or $\sim 0.8 \%$ weight change). Not enough washcoat could be collected from the porcelain dish to be weighed accurately. Therefore, this thermal cycling technique caused minor washcoat loss.

\section{Conclusions}

The focus of recent work has been catalyst characterization, specifically SEM and catalyst cycling, of the supports. The results are summarized here:

- SEM images of catalysed metal foams reveal a heterogeneous washcoat thickness and an inconsistent washcoat deposition. Qualitatively, no distinct differences are seen between virgin and "used" metal foams or metal foams with different ppi and densities.

- SEM images of catalysed ceramic monoliths reveal a more uniform washcoat compared to metal foams.

- Thermal and mechanical cycling did not remove an appreciable amount of washcoat on a metal foam. 


\section{Recommendations}

There is a need to develop a consistent and uniform washcoat procedure for metal foams. Future work at Louisiana State University should focus on electrodeposition as a washcoat deposition technique. In addition, new catalysts and promoters, such as Ru and Mn, respectively, should be evaluated for their PROX activity and selectivity.

\section{Acknowledgements}

The authors would like to thank the United States Department of Energy, under Contract Number DE-FG-01NT41277, for funding of this research. The authors would also like to thank the Velev research group from the Department of Chemical and Biomolecular Engineering at North Carolina State University, Raleigh, NC, for use of their furnace. The catalysts used in this research were prepared by Environex, Inc., Wayne, PA.

\section{References}

1. Chin, P., X. Sun, G.W. Roberts, J.J. Spivey, A. Sirijaruphan, J.G. Goodwin, and R.W. Rice, Reformulation of Coal-Derived Transportation Fuels: Selective Oxidation of Carbon Monoxide on Metal Foam Catalysts. U.S. Department of Energy Annual Report \#41277R01, 2002. North Carolina State University: Raleigh, NC.

2. Roberts, G.W., P. Chin, X.L. Sun, and J.J. Spivey, Applied Catalysis B Environmental, 2003. 46(3): p. 601-611.

3. Korotkikh, O. and R. Farrauto, Catalysis Today, 2000. 62(2-3): p. 249-254.

4. Chin, P., G.W. Roberts, J.J. Spivey, A. Sirijaruphan, J.G. Goodwin, and R.W. Rice, Reformulation of Coal-Derived Transportation Fuels: Selective Oxidation of Carbon Monoxide on Metal Foam Catalysts. U.S. Department of Energy Annual Report \#41277R02, 2003. North Carolina State University: Raleigh, NC.

5. Chin, P., G.W. Roberts, J.J. Spivey, A. Sirijaruphan, S. Pansare, J.G. Goodwin, and R.W. Rice, Reformulation of Coal-Derived Transportation Fuels: Selective Oxidation of Carbon Monoxide on Metal Foam Catalysts. U.S. Department of Energy Annual Report \#41277R03, 2004. North Carolina State University: Raleigh, NC.

6. Chin, P., X. Sun, G.W. Roberts, J.J. Spivey, A. Sirijaruphan, S. Pansare, J.G. Goodwin, and R.W. Rice, Reformulation of Coal-Derived Transportation Fuels: Selective Oxidation of Carbon Monoxide on Metal Foam Catalysts. U.S. Department of Energy Technical Reports, 2002-2004. North Carolina State University: Raleigh, $\mathrm{NC}$. 
7. Brundle, C.R., C.A. Evans Jr., and S. Wilson, Encyclopedia of Materials Characterization: Surfaces, Interfaces, Thin films. Materials Characterization Series, ed. L.E. Fitzpatrick. 1992, Stoneham, MA: Butterworth-Heinemann.

8. Potts, D., A. Krawiec, J. Greenwood, and M. Cottle, Senior Design Project Report: Surface Area Measurement of Copper Foam. Senior Design Project, 2002. North Carolina State University: Raleigh, NC.

9. Heck, R.M., R.J. Farrauto, and S.T. Gulati, Catalytic Air Pollution Control Commercial Technology. 2nd Edition ed. 2002, New York, NY: John Wiley \& Sons, Inc.

\section{List of Acronyms and Abbreviations}

\begin{tabular}{|c|c|}
\hline Abbreviation & Definition \\
\hline$\rho$ & Cell density \\
\hline BSE & Backscattered image on a SEM \\
\hline cpsi & Cells per square inch \\
\hline EDS & Energy dispersive $\mathrm{x}$-ray spectroscopy \\
\hline GHSV & Gas hourly space velocity \\
\hline I.D. & Inner diameter \\
\hline ITKA & Isotopic transient kinetic analysis \\
\hline ppi & Pores per (linear) inch \\
\hline PROX & Preferential oxidation \\
\hline PEMFC & Proton exchange membrane fuel cell \\
\hline r-WGS & Reverse water-gas-shift \\
\hline SE & Secondary image on a SEM \\
\hline SEM & Scanning electron microscopy \\
\hline TPD & Temperature programmed desorption \\
\hline TOS & Time on stream \\
\hline
\end{tabular}

